\section{Incidence of cervical intraepithelial lesions in a population of adolescents treated in public health services in Rio de Janeiro, Brazil}

\author{
Incidência de lesões intra-epiteliais cervicais em \\ população de adolescentes atendidas em serviço \\ público de saúde no Rio de Janeiro, Brasil
}

Denise Leite Maia Monteiro 1,2 Alexandre José Baptista Trajano ${ }^{3}$ Kátia Silveira da Silva 4

Fábio Bastos Russomano 4
${ }_{1}$ Centro Universitário Serra dos Órgãos, Teresópolis,

Brasil.

2 Ambulatório de Ginecologia para Adolescentes, Hospital Geral de Jacarepaguá, Rio de Janeiro, Brasil.

3 Centro Biomédico,

Universidade do Estado do

Rio de Janeiro, Rio de Janeiro, Brasil.

4 Instituto Fernandes

Figueira, Fundação Oswaldo

Cruz, Rio de Janeiro, Brasil.

Correspondence

D. L. M. Monteiro

Centro Universitário Serra

dos Órgãos.

Rua Almirante Tamandaré 66 sala 851, Rio de Janeiro, $R J$

22210-060, Brasil.

denimonteiro2@yahoo.com.br

\section{Abstract}

This study aimed to estimate the incidence and types of cervical cytopathological findings in adolescents who were treated in public health services between 1993 and 2006. This is a cohort study, with the following inclusion criteria: $<20$ years of age, sexually-active, without cervical lesions upon entry into the study or sexually active $<1$ year. The data were collected from 403 adolescents' medical records. Incidence density of cytopathological alterations was estimated and the actuarial method was used to calculate the 5year incidence during follow-up after sexual initiation. In the first year of sexual activity, the incidence of cervical lesions was $24.1 \%$. The incidence decreased to 3-8\% over the following 4 years. The incidence density was 4.7 cases per 100 persons per year. The first abnormal cytological diagnosis showed atypical squamous cells of undetermined significance (ASCUS) in 5.5\% (22) of patients, lowgrade squamous intra-epithelial lesions (LSIL) in 28\% (113), and high-grade squamous intraepithelial lesions (HSIL) in 3\% (12). Eight (67\%) cases of HSIL occurred during the first year of sexual activity. The incidence of cytopathological findings at beginning of sexual life is high, suggesting the importance of including sexually-active adolescents in cervical cancer prevention programs.

Cervical Intraepithelial Neoplasia; Adolescents; Papillomaviridae

\section{Introduction}

Several recent studies have suggested that the incidence of intraepithelial cervical lesions rises during adolescence $1,2,3$, being directly related to the frequency of sexual activity and to an increase in the incidence of human papilloma virus infection among that population 4,5,6.

Adolescence is a defining moment for sexual identity in which individuals may have several sexual partners and frequently experience a feeling of invulnerability, believing that nothing will happen to them 7 . Both the behavioral aspects related to cultural modifications and factors that have a biological nature, such as the migration of the transformation zone, exposing a region of cylindrical endocervical epithelium, represent additional risks that increase the vulnerability of adolescents to sexually-transmitted diseases (STD), and to HPV infection in particular 8 .

It is important to note that the average age at the onset of sexual activity has been decreasing across different social strata; it can therefore be considered a general tendency. An official Brazilian study showed that from 1984 to 1998 the mean age at the onset of sexual activity among women decreased from 16 to 15.2 years of age 9,10 .

Cervical cancer is a rare condition during adolescence 11, but it has already been reported in some studies 12,13. At the global level, cervical cancer is still the second most common malig- 
nancy in women, second only to breast cancer. It is estimated that 510,000 new cases and 288,000 deaths occur each year due to cervical cancer; $80 \%$ of these occur in developing countries 14 .

The Papanicolaou smear (Pap smear) is an effective and low-cost cervical cancer screening method, contributing to a prevention of up to $80 \%$ of deaths caused by cervical cancer 15 , as observed in developed countries. However, despite having been one of the first countries in the world to adopt such a test as a screening tool, in Brazil cervical cancer is still a serious public health problem, with diagnoses being frequently made at advanced stages of the disease 16 .

Guidelines related to the beginning and frequency of cervical screening vary from country to country. Protocols published by the American Cancer Society and the American College of Obstetricians and Gynecologists recommend yearly screening Pap smears between the ages of 21 and 30 . After that age, when three consecutive yearly smears have shown no abnormal findings, the Pap smear can be performed every two or three years $11,17,18$. In Brazil, the National Program Against Cervical and Breast Cancer (Programa Viva Mulher) develops actions aimed at women between 25 and 59 years of age 16 . Therefore, adolescents are excluded from all prevention programs.

The target age group in the latter program was probably chosen due to several factors: the transitory nature of the HPV infection; the possibility of spontaneous regression of the cervical intraepithelial lesions, even high-grade ones, in adolescents; and the rare occurrence of cancer at that age. For those reasons, there are limited data about the rate of progression of low-grade squamous intra-epithelial lesions (LSIL) in adolescents 11, and the risk of progression of highgrade squamous intraepithelial lesions (HSIL) remains unknown 19 .

The observed decrease in the mean age at the time of diagnosis of HPV-induced intraepithelial lesions, which are becoming more frequent among adolescents and young women below the age of 3020,21 , could translate into a higher incidence of cervical cancerin upcomingyears, as well as into a higher demand for diagnostic and therapeutic procedures for precursor lesions that will represent a major challenge for public health 22 .

At the Gynecology Service in the Jacarepaguá General Hospital, in the city of Rio de Janeiro, Brazil, we have detected, from 1993 until the present day, a decrease in the mean age at the onset of sexual activity age among adolescents, as well as the occurrence of STD and squamous intraepithelial lesions (SIL), including cases of pre-invasive cervical disease and even one case of cervical cancer 12 .
The objective of this study is to estimate the incidence and identify the types of cervical cytopathological findings in adolescents followed in our service since their first year of sexual activity.

\section{Methods}

The study population comprised female adolescents aged between 11 and 19 years and followed for a period of up to seven years, between 1993 and 2006, as outpatients at the Ambulatório de Ginecologia para Adolescentes, Hospital Geral de Jacarepaguá, a public institution, in the city of Rio de Janeiro, providing secondary and tertiary care as a reference for local primary services integrated to the Unified National Health System (SUS).

It consists of a general day-care clinic to which young girls are promptly referred by the Adolescent Care Service, which has been operating in the hospital since 1991 and offers integral and multidisciplinary care to male and female teenagers. For this reason, a great number of adolescents (58\%) arrive at the clinic before starting their sexual life. Only $20 \%$ of the adolescents look spontaneously for the Gynecology Clinic without having been seen previously at the general clinic.

This research project consists of a concurrent and non-concurrent cohort study based on the analysis of the Pap smear results of sexually-active adolescents followed as outpatients. In order to estimate the incidence of abnormal pathological findings we determined a minimum sample size of 246 patients, based on an estimated incidence of $20 \%$, an alpha error of $5 \%$, and a sampling error of $4 \%$.

The inclusion criteria used for building the study group were: age below 20 years, active sex life, normal Pap smear upon entry into the study, and having had at least two Pap smears during their lifetime. The adolescents whose first cytopathological test showed abnormal results were excluded from the study, except those who had started their sexual life less than a year before entering the study. In such situations, the patient was considered as having developed the condition half way into her sexual life.

A total of 2,016 adolescents were followed in our Gynecology Clinic between August 1993 and December 2006; of these, 846 were sexually active (42\%), and 403 fulfilled the study criteria, being thus selected for the study. The 443 patients who were submitted to only one cytophatological test were excluded from the analysis (Figure 1).

The data were obtained from the patients' medical records, which include clinical and epi- 
Figure 1

Fluxogram for inclusion in the study.

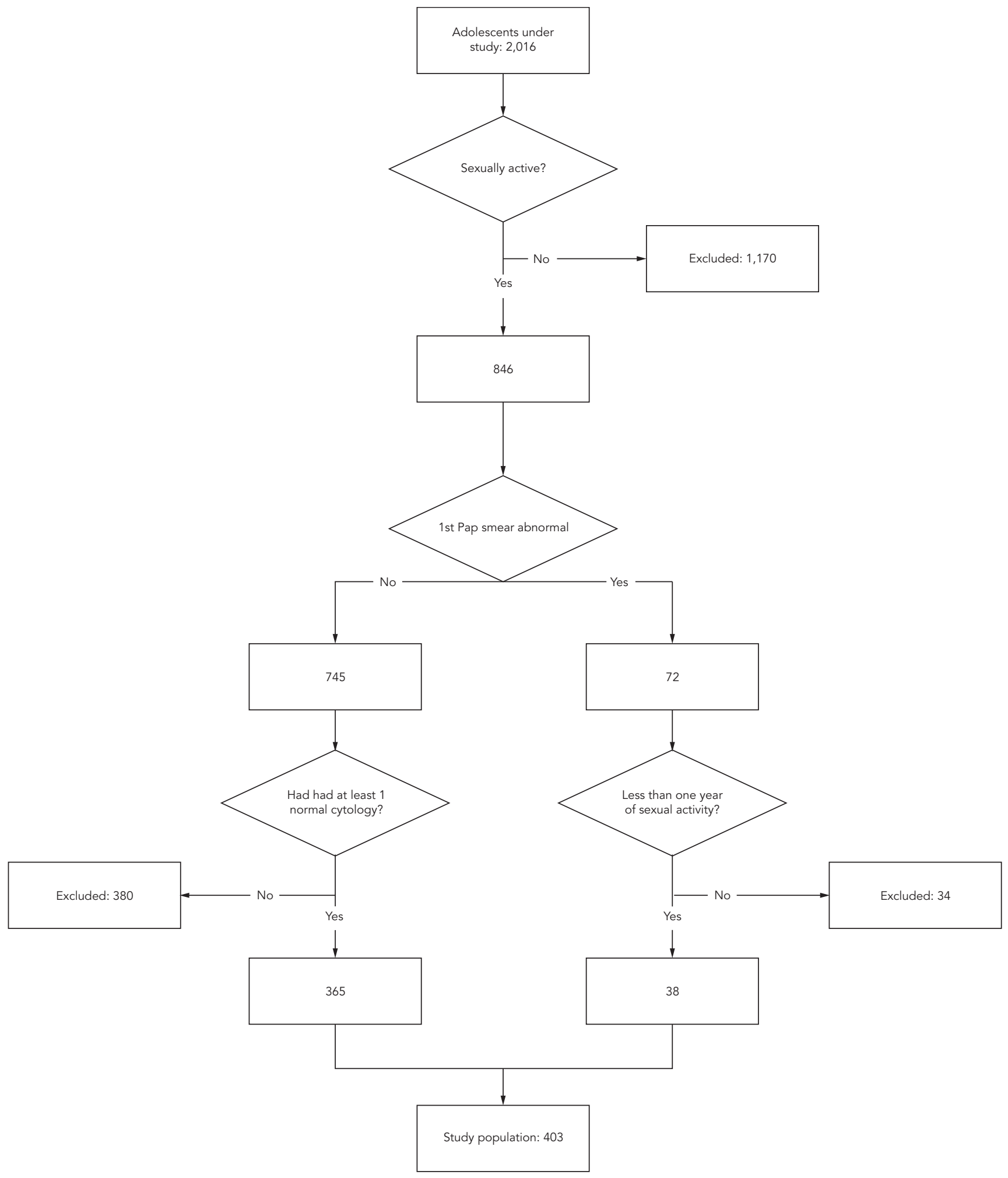


demiological records (age, marital status, family income, schooling, and main occupation), risk factors described in medical literature (age of onset of sexual activity; number of sexual partners; prior STD; number of pregnancies; age at first pregnancy; alcohol, tobacco and illicit drugs consumption; and use of contraceptive methods), as well as from the records of physical gynecological examinations and results from cervical cytology, colposcopy and histopathology.

The Hospital Geral de Jacarepaguá board of directors expressly authorized the research to be based on the patient's medical records. Those who belonged to the concurrent cohort were informed about their participation in the study and gave their free informed consent. The study is part of a research project developed as a doctorate thesis and was approved by the Research Ethics Committee of the Instituto Fernandes Figueira, Fundação Oswaldo Cruz.

All patients were seen at least once by the principal investigator, who performed a gynecological examination using a Collins speculum to evaluate the vagina and cervix, a Schiller test, and collected a sample for the colpocytology. The smears were prepared in the conventional manner (Papanicolaou stain) and analyzed in a large central laboratory called SITEC (Seção Integrada de Tecnologia em Citopatologia), located within the Pathology Section of the National Cancer Institute. This lab is considered a benchmark for the public health sector in the state of Rio de Janeiro and performs every cytopathological examination in Rio's public health system, as well as in many other municipalities. The lab's internal quality control system determines that every positive smear and $10 \%$ of the negative smears must be rechecked by a medical cytopathologist, according to the parameters established by the computerized quality system of gynecological cytology, established by the Ministry of Health of Brazil - Sistema de Informação de Controle do Câncer do Colo do Útero (SISCOLO). The results were given according to the nomina adopted by the Programa Viva Mulher, initially using Richart's 23 classification which was later updated to Bethesda's 24 .

The outcomes of this study were the incidence and types of cytopathological alterations during the first five years of sexual activity.

In order to establish the profile of the population studied, the following variables were considered: age upon admission to the study and at the onset of sexual activity, family income, level of formal education, number of sexual partners and previous STD. Categorical variables were described as proportions with a confidence interval of $95 \%$ (95\%CI), while continuous variables were expressed as means, standard deviations and medians.

The incidence of each cytopathological alteration during the follow-up after sexual initiation was described as the proportion of cytopathological alterations (with a 95\%CI) related to the total of adolescents at risk at the start of follow-up.

The incidence density was estimated using the sum of people/year as the denominator, taking into account the time of ambulatorial followup for each adolescent in the study population. When the adolescent returned to the Gynecology Clinic after an interval of $12 \pm 2$ months, this was considered to be one year of follow-up since study admission or latest Pap smear. Follow-up period ranged from between one and five years for each patient.

In order to estimate the risk of cytopathological alterations during the first five years of sexual activity, a survival analysis was performed using the actuarial method. The survival curve was built using the Kaplan-Meier method 25. The data were analyzed statistically using SPSS software for Windows (SPSS Inc., Chicago, Estados Unidos).

\section{Results}

The study group, composed of 403 adolescents, was followed for a period of up to five years after the beginning of their sexual life by means of cytopathological examinations every six months. The adolescents' age at their first visit varied from 11 to 19 years, averaging 15.6 years. The mean age at the onset of sexual activity was 14.8 years, $11.4 \%$ (46) were married or lived with their partners and the mean family income was 4.2 times the minimum wage. Most of the patients (58.3\%) had education to elementary level. Regarding marital status, the mean number of sexual partners was 1.8, and the median number was one. $63 \%$ (254) of patients reported having only one sexual partner, and $30.5 \%$ (123) claimed to have 2 or 3 partners. A history of STDs such as syphilis, hepatitis $\mathrm{C}$ and Chlamydia, Gonococcus, Herpes and HIV infection was reported by $5.7 \%$ (23) of adolescents (Table 1).

The first abnormal cytology consisted of atypical squamous cells of undetermined significance (ASCUS) in 5.5\% (22), LSIL in 28\% (113) and HSIL in 3\% (12) of adolescents. Most diagnoses of HSIL $(67 \% ; 8 / 12)$ occurred within the first year of sexual activity (Table 2).

The calculated accumulated incidence in each period of time is shown on Table 3. In the first year of sexual life the incidence was $24.1 \%$ (95\%CI: $20.0-28.5)$; and in the following four years it was $8 \%$ (95\%CI: $5.2-11.7), 7.4 \%$ (95\%CI: 
Profile of the adolescents included in the study.

\begin{tabular}{lc}
\hline Clinical-demographic characteristics & $\%(95 \% \mathrm{Cl})$ \\
\hline Sexual initiation & \\
10 - 15 years & $40.9(36.1-45.9)$ \\
15 -19 years & $59.1(54.1-63.9)$ \\
Average & $14.8 \pm 1.5$ \\
Marital status & $11.4(8.5-14.9)$ \\
$\quad$ Married & $88.6(85.1-91.5)$ \\
Single & $48(43.0-53.0)$ \\
Family income (as a multiple of the minimum wage) & $52(47.7-57.7)$ \\
1 - 4 & $4.2 \pm 2.8$ \\
4 F-30 & \\
Average & $58.3(53.3-63.2)$ \\
Schooling & $41.7(36.8-46.7)$ \\
Elementary school & \\
High school & $63(58.1-67.7)$ \\
Number of partners & $37(32.2-41.9)$ \\
1 & \\
2 F-30 & $5.7(3.6-8.4)$ \\
History of sexual transmitted diseases & $94.3(91.5-96.3)$ \\
Yes & \\
No &
\end{tabular}

Table 2

Cytopathological alterations in adolescents after the beginning of sexual life to five years of intervals of follow-up.

\begin{tabular}{lcc}
\hline & $\mathbf{n}$ & $\%(\mathbf{9 5} \% \mathrm{Cl})$ \\
\hline Cytopathological alterations & & $28.0(23.7-32.7)$ \\
LSIL & 113 & $3.0(1.5-5.1)$ \\
HSIL & 12 & $5.5(3.4-8.1)$ \\
ASCUS & 22 & $36.5(31.8-41.4)$ \\
Total & 147 & - \\
Incidence density of cytopathological alterations & 403 & - \\
Number of followed patients & 147 & - \\
Patients with altered cytopathology & 3,119 & -
\end{tabular}

ASCUS: atypical squamous cells of undetermined significance; HSIL: high-grade squamous intraepithelial lesions; LSIL: lowgrade squamous intra-epithelial lesions.

4.4-11.4), 3.3\% (95\%CI: 1.1-7.5), and 4.3\% (95\%CI: $0.9-12)$, respectively. Note that the incidence of abnormal cytological findings in the first year of sexual activity is three times higher than in the second year. Overall, after five years of sexual activity the risk of acquiring cytopathological alterations was $40 \%$.
Almost half the patients who had abnormal findings in their first year already had the lesion after six months of sexual activity (Figure 2).

The comparison between the sexually-active group that was not included in the study (443 adolescents) and the studied sample (403) did not present any statistically significant differences 
Table 3

Incidence and probability of cytopathological alterations per year of sexual activity.

\begin{tabular}{lccccccc}
\hline $\begin{array}{l}\text { Year of } \\
\text { sexual } \\
\text { activity }\end{array}$ & $\begin{array}{c}\text { Number of } \\
\text { patients in the } \\
\text { beginning of } \\
\text { the period }\end{array}$ & $\begin{array}{c}\text { Number of } \\
\text { altered } \\
\text { cytopathologies } \\
\text { in the period }\end{array}$ & Dropouts & Censored * & $\begin{array}{c}\text { Incidence of } \\
\text { cytopathological } \\
\text { alterations } \\
(\mathbf{9 5 \% C l )}\end{array}$ & $\begin{array}{c}\text { Probability of } \\
\text { cytopathological } \\
\text { alterations } \\
\text { per year }\end{array}$ & $\begin{array}{c}\text { Accumulated } \\
\text { probability of } \\
\text { cytopathological } \\
\text { lesions at the } \\
\text { end of each } \\
\text { period }\end{array}$ \\
\hline 1st year & 403 & 97 & 0 & 97 & $24.1(20-28.5)$ & 0.241 & 0.241 \\
2nd year & 306 & 24 & 15 & 39 & $8.0(5.2-11.7)$ & 0.080 & 0.302 \\
3rd year & 267 & 18 & 47 & 65 & $7.4(4.4-11.4)$ & 0.074 & 0.353 \\
4th year & 202 & 5 & 98 & 103 & $3.3(1.1-7.5)$ & 0.033 & 0.375 \\
5th year & 99 & 3 & 58 & 61 & $4.3(0.9-12)$ & 0.043 & 0.402 \\
\hline
\end{tabular}

* Patients who already presented the outcome or who abandoned the follow-up.

Figure 2

Probability of the occurrence of cytopathological alterations estimated by the Kaplan-Meier method during the first year of follow-up after the onset of sexual activity.

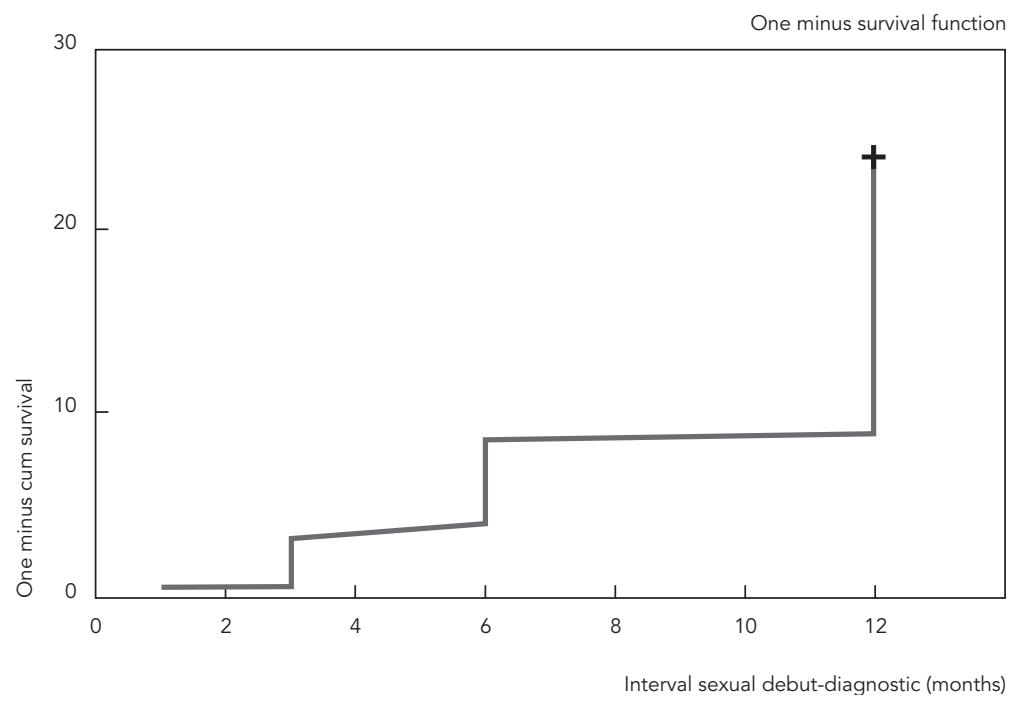

regarding the demographic data and the risk factors already described; the exception was regarding the previous history of STDs, which was three times higher in the group under study (data not shown).

\section{Discussion}

The need for the development of effective strategies for the prevention of cervical cancer at younger ages makes the cytopathological evaluation of the target population an essential piece of research required to determine the ideal moment for intervention and its subsequent benefits. The first studies on this issue had a cross-sectional 
design and therefore did not allow for that kind of evaluation 20,26 . In recent years, longitudinal studies aimed at determining the incidence and analyzing cytopathological abnormalities in adolescents have been performed 1,2,4,6. In Brazil, because the national health service program, Programa Viva Mulher, does not include this age group, and because of the small number of gynecological care services for adolescents, the data are even scarcer.

This study found that after five years of follow-up, $36.5 \%$ of adolescents presented cytopathological abnormalities; a similar result (37\%) was reported by Brown et al. 4 . Nevertheless, the incidence of SIL in the present study was greater than in Brown's, perhaps due to their high incidence of ASCUS (16.7\%).

The incidence of cytopathological alterations in different studies involving adolescents is shown in Table 4. The discrepancy in the results is probably due to the fact that the cytological diagnosis of ASCUS is highly variable, even when strict criteria are used 27 . That raises the possibility that some LSIL diagnoses in this study, if analyzed by other cytopathologists, could have been classified as ASCUS.

The present study indicates that the incidence of cytopathological alterations is higher in the first year of sexual activity (24.1\%), declining in the two following years to approximately one third, i.e. if the adolescent did not acquire alterations during the first year of sexual activity, her risk is much lower in the following years. As is the case with most STDs, HPV infection frequently happens at the very beginning of sexual life 28,29. Therefore, the incidence is higher at younger ages and tends to decline at older ages, after transitory infections are resolved. Such findings ratify the recommendations for a conservative clinical approach during adolescence, avoiding more aggressive procedures such as cervical surgery $1,18,30,31$.

Longitudinal studies using HPV DNA detection techniques confirm that HPV infection rates are higher among adolescents, showing a cumulative prevalence of $82 \%$, and an average of 4.9 different types of HPV 4 . A prospective study among young American females who were initially HPV-negative showed that $34 \%$ had an incident infection in 24 months 32 and that the patients had a $70 \%$ chance of acquiring a second type of HPV within 24 months of the initial infection 5 . A similar study showed that $55 \%$ of adolescents acquired the infection within three years 6 .

Cytopathological results may differ from histopathological findings, which are considered the gold standard, however, in a previous prevalence study undertaken with the same population of patients who originated this cohort $63.8 \%$ of the cytopathological results agreed with the histopathological results 12 , an index corroborated by the literature $(65.1 \% 33$ and $60.2 \% 34)$.

The characteristics of the population of adolescents studied in this research are similar to those of the general population regarding the age of onset of sexual activity and the adolescent's level of education. We observed that adolescents seek gynecological assistance at the age of 15, soon after starting sexual activity; the mean age at their first sexual intercourse is similar to that published in an official revision, which reported 15.2 years 10 . Regarding the adolescent's schooling, our results were endorsed by the data from the Pesquisa Nacional por Amostra de Domicílios (PNAD-2004), which reported $58 \%$ of the population with primary education in the Southeast Region of the country (compared with $44 \%$ in Brazil as a whole, and $28 \%$ in the North and Northeast Regions) 35 .

Table 4

Incidence of cytopathological alterations in different studies involving adolescents.

\begin{tabular}{lcccc}
\hline Study & ASCUS & LSIL & HSIL & Total \\
\hline Edelman et al. 3 & 12.2 & 7.7 & 0.7 & 20.7 \\
Moscicki et al. 6 & Not reported & 25.0 & 5.0 & 30.0 \\
Brown et al. 4 & 16.7 & 18.5 & 0.6 & 37.0 \\
Rama et al. 39 & 11.9 & 7.7 & 0.7 & 20.5 \\
Wright et al. 1 & Not reported & 5.7 & 3.0 & 6.4 \\
Present study & 5.5 & 28.0 & 36.5 \\
\hline
\end{tabular}

ASCUS: atypical squamous cells of undetermined significance; HSIL: high-grade squamous intraepithelial lesions; LSIL: lowgrade squamous intra-epithelial lesions. 
Differences regarding marital status and family income were noted. Our cohort has a higher proportion of married adolescents than the state of Rio de Janeiro in 2000 (7.2\%), and a lower family income than that observed in the state, in 200335. Despite the lower income of the study group, which could represent poorer access to information, healthcare and STD prevention, there is easier access to the health unit, because of the differentiated approach in a service dedicated to adolescents; that could compensate the negative repercussion of the group's poor economic situation.

Several epidemiological studies performed within the last 30 years showed that the risk of cervical cancer is highly influenced by the precocious beginning of sexual activity and by a multiplicity of sexual partners 32,36 . However, a longitudinal study made with adolescents and young adults, despite showing that each new partner caused a 10-fold increase in the risk of acquiring an HPV infection, didn't demonstrate any significant association between the number of partners and the development of LSIL ${ }^{6}$. In the prevalence study we previously performed, the number of partners was not related to cervical lesions 12 . In the present study, a great proportion of adolescents reported having only one partner; that is similar to what was shown in a study conducted by the Centers for Disease Control and Prevention, which reported an average of 1.4 partners among adolescents 37 .

The loss of follow-up of more than 50\% (443) of the sexually-active patients appears to be the most important limitation of this study. Among these patients, $6.2 \%$ had cytopathological alterations $($ ASCUS $=1.4 \%$; LSIL $=4.3 \%$; and HSIL $=$ $0.5 \%$ ), but because they did not conclude the follow-up they were excluded from the study. That might have resulted in an underestimation of the incidence of lesions. However, there were no statistically significant differences between that group and the studied cohort. Furthermore, the loss of follow-up on adolescents seems habitual and is widely observed in recent literature with high percentages ranging from $30 \% 1$ and $34.6 \% 37$ to $65 \% 30$

On the other hand, the fact that a higher number of patients in the group under study had previous STD diagnoses points to the possibility of a selection bias that could have caused an overestimation of the incidence of cytopathological alterations. Because it was not possible to identify the presence of HPV through molecular diagnosis, its relation to cytopathological alterations in that group could not be assessed.

All things considered, we found a high proportion of adolescents with cytopathological alterations at the very beginning of their sexual lives, with the most serious lesions during the first year of sexual activity, six times higher than were found after five years. That could be explained by the high rates of regression among that age group described by several authors 1,6,30. These data point to the importance of the inclusion of sexually-active adolescents in national cervical cancer prevention programs.

Allied to a more comprehensive public health policy, sexual health education programs for adolescents 28 have a primordial role in primary prevention of HPV infection through the promotion of condom use. At the moment, with the release of new vaccines against HPV, there are great expectations that these will become important preventive tools, if integrated to the screening programs aimed at the early detection of cervical cancer 38 


\section{Resumo}

O objetivo foi estimar a incidência e os tipos das alterações citopatológicas cervicais em adolescentes acompanhadas em serviço público entre 1993-2006. Estudo de coorte, tendo como critérios de inclusão: idade < 20 anos, apresentar atividade sexual, citopatologia negativa para lesão cervical na entrada do estudo ou tempo de atividade sexual $<1$ ano. Os dados foram coletados de prontuários de 403 adolescentes. Foi estimada densidade de incidência, e para o cálculo da incidência das alterações citopatológicas referentes a cinco anos de acompanhamento após atividade sexual foi utilizado o método atuarial. No primeiro ano de atividade sexual, a incidência de lesões cervicais foi de $24,1 \%$. Houve redução da incidência nos quatro anos subseqüentes com variação entre 3-8\%. A densidade de incidência foi de 4,7 casos/100 pessoas-ano. O primeiro diagnóstico citológico anormal mostrou atipias em células escamosas de significado indeterminado (ASCUS) em 5,5\% (22) das pacientes, lesão intra-epitelial escamosa de baixo grau (LSIL) em 28\% (113) $e$ lesão intra-epitelial escamosa de alto grau (HSIL) em $3 \%$ (12). Oito (67\%) dos casos de HSIL ocorreram no primeiro ano de atividade sexual. A incidência de alterações citopatológicas é alta no início da vida sexual, sugerindo ser importante a inclusão das adolescentes sexualmente ativas no Programa de Controle do Câncer de Colo Uterino.

Neoplasia Intra-Epitelial Cervical; Adolescentes; Papillomaviridae

\section{Contributors}

D. L. M. Monteiro participated in the overall study concept, data collection, data analysis, and drafting of the article. A. J. B. Trajano providing critical reviews throughout the thesis development process and final drafting of the article. K. S. Silva and F. B. Russomano collaborated in the study design, elaboration, and implementation of the statistical analysis and review of the manuscript.

\section{References}

1. Wright JD, Davila RM, Pinto KR, Merritt DF, Gibd RK, Rader JS, et al. Cervical dysplasia in adolescents. Obstet Gynecol 2005; 106:115-20.

2. Simsir A, Brooks S, Cochran L, Bourquin P, Ioffe OB. Cervicovaginal smear abnormalities in sexually active adolescents: implications for management. Acta Cytol 2002; 46:271-6.

3. Edelman M, Fox AS, Alderman EM, Neal W, Shapiro A, Silver EJ, et al. Cervical Papanicolaou smear abnormalities in inner city Bronx adolescents: prevalence, progression and immune modifiers. Cancer 1999; 87:184-9.

4. Brown DR, Shew ML, Qadadri B, Neptune N, Vargas $\mathrm{M}, \mathrm{Tu} \mathrm{W}$, et al. A longitudinal study of genital human papillomavirus infection in a cohort of closely followed adolescent women. J Infect Dis 2005; 191:182-92.

5. Ho GYF, Studentsov Y, Hall CB, Bierman R, Beardsley L, Lempa M, et al. Risk factors for subsequent cervicovaginal human papillomavirus (HPV) infection and the protective role of antibodies to HPV16 virus-like particles. J Infect Dis 2002; 186:737-42.
6. Moscicki AB, Hills N, Shiboski S, Powell K, Jay N, Hanson E, et al. Risks for incident human papillomavirus infection and low-grade squamous intraepithelial lesion development in young females. JAMA 2001; 285:2995-3002.

7. Taquette SR, Vilhena MM, Paula MC. Doenças sexualmente transmissíveis e gênero: um estudo transversal com adolescentes no Rio de Janeiro. Cad Saúde Pública 2004; 20:282-90.

8. Moscicki AB, Winkler B, Irwin Jr. CE, Schachter J. Differences in biologic maturation, sexual behavior, and sexually transmitted disease between adolescents with and without cervical intraepithelial neoplasia. J Pediatr 1989; 115:487-93.

9. Melo AV, Yazaki LM. O despertar do desejo. In: Secretaria de Economia e Planejamento, Fundação Sistema Estadual de Análise de Dados, organizador. 20 anos no ano 2000: estudos sócio-demográficos sobre a juventude. São Paulo: Fundação Sistema Estadual de Análise de Dados; 1998. p. 119-25.

10. Ministério da Saúde. Pesquisa sobre comportamento sexual e percepções da população brasileira sobre HIV/AIDS. Brasília: Ministério da Saúde; 2000. 
11. Saslow D, Runowicz CD, Solomon D, Moscicki AB, Smith RA, Eyre HJ, et al. American Cancer Society guideline for the early detection of cervical neoplasia and cancer. CA Cancer J Clin 2002; 52:342-62.

12. Monteiro DLM, Trajano AJB, Silva KS, Russomano FB. Pre-invasive cervical disease and uterine cervical cancer in Brazilian adolescents: prevalence and related factors. Cad Saúde Pública 2006; 22: 2439-48.

13. Nascimento MI, Pires ES, Gil DQ, Nunes GG, Balboa V, Stasiaki FV, et al. Características de um grupo de adolescentes com suspeita de neoplasia intra-epitelial cervical. Rev Bras Ginecol Obstet 2005; 27:619-26.

14. Pagliusi S. Human papillomavirus infection and cervical cancer. http://www.who.int/vaccine research/diseases/hpv/en/ (accessed on 26/Oct/ 2006).

15. Instituto Nacional de Câncer. Estimativa 2006: incidência de câncer no Brasil. http://www.inca.gov. br/estimativa/2006 (accessed on 10/Feb/2007).

16. Instituto Nacional de Câncer. Programa nacional de controle do câncer do colo do útero e de mama-Viva Mulher. Prevenção e detecção 2002. http:/ / www. inca.gov.br/prevencao/programas/pncccum/ $\mathrm{html}$ (accessed on 30/Jun/2004).

17. Centers for Disease Control and Prevention, Workowski KA, Berman SM. Sexually transmitted diseases treatment guidelines, 2006. MMWR Recomm Rep 2006; 55(RR-11):1-94.

18. Wright Jr. TC, Cox JT, Massad LS, Carlson J, Twiggs LB, Wilkinson EJ, et al. 2001 consensus guidelines for the management of women with cervical intraepithelial neoplasia. Am J Obstet Gynecol 2003; 189:295-304.

19. Moscicki AB, Shiboski S, Hills NK, Powell KJ, Jay N, Hanson EN, et al. Regression of low grade squamous intra-epithelial lesions in young women. Lancet 2004; 364:1678-83.

20. Sadeghi SB, Hsieh EW, Gunn SW. Prevalence of cervical intraepithelial neoplasia in sexually active teenagers and young adults. Results of data analysis of mass Papanicolaou screening of 796,337 women in the United States in 1981. Am J Obstet Gynecol 1984; 148:726-9.

21. Lüdicke F, Stalberg A, Vassilakos P, Major AL, Campana A. High and intermediate-risk human Papillomavirus infection in sexually active adolescent females. J Pediatr Adolesc Gynecol 2001; 14:171-4.

22. Gonçalves WC, Leonardo NDB, Serapião JJ. Influência atual do HPV na sexualidade. Femina 2003; 31:823-5.

23. Richart RM. The natural history of cervical intraepithelial neoplasia. Clin Obstet Gynecol 1967; 10:748-85.

24. National Cancer Institute. Bethesda system 2001. http://www.bethesdaterminology2001.pdf (accessed on 20/Mar/2003).

25. Moscicki AB. Genital HPV infections in children and adolescents. Obstet Gynecol Clin North Am 1996; 23:675-97.
26. Tarkowski TA, Koumans EH, Sawyer M, Pierce A, Black CM, Papp JR, et al. Epidemiology of human papillomavirus infection and abnormal cytologic test results in an urban adolescent population. J Infect Dis 2004; 189:46-50.

27. Souza JHK, Kalil IV, Leite JM, Geber S. Avaliação de lâminas de colpocitologia oncótica previamente diagnosticadas como ASCUS: comparação interensaio e interobservadores. Rev Bras Ginecol Obstet 2004; 26:233-40.

28. Schiffman MH. Recent progress in defining the epidemiology of human papillomavirus infection and cervical neoplasia. J Natl Cancer Inst 1992; 84:394-8.

29. Villa LL. Human papillomaviruses and cervical cancer. Adv Cancer Res 1997; 71:321-41.

30. Moore K, Cofer A, Elliot L, Lanneau G, Walker J, Gold MA. Adolescent cervical dysplasia: histological evaluation, treatment and outcomes. Am J Obstet Gynecol 2007; 197:141.e1-141.e6.

31. Moscicki AB. Impact of HPV infection in adolescent populations. J Adolesc Health 2005; 37(6 Suppl): S3-9.

32. Ho GYF, Bierman R, Beardsley L, Chang CJ, Burd RD. Natural history of cervicovaginal papillomavirus infection in young women. N Engl J Med 1998; 338:423-8.

33. Pinho AA, Mattos MCFI. Validade do exame colpocitológico na detecção de lesões pré-neoplásicas e neoplásicas de colo do útero. J Bras Patol Med Lab 2002; 38:225-31.

34. Roberto Neto A, Ribalta JCL, Focchi J, Baracat EC. Avaliação dos métodos empregados no Programa Nacional de Combate ao Câncer do Colo Uterino do Ministério da Saúde. Rev Bras Ginecol Obstet 2001; 23:209-16.

35. Instituto Brasileiro de Geografia e Estatística. Síntese de indicadores sociais, 2005. http://www.ibge. gov.br/home/estatistica/populacao/indicadoresminimos/sinteseindicsociais2005/pdf (accessed on $12 / \mathrm{Jul} / 2007$ ).

36. Fletcher RH, Fletcher SW, Wagner EH. Epidemiologia clínica: elementos essenciais. 4a Ed. Porto Alegre: Editora Artmed; 2006.

37. Vetrano G, Lombardi G, Di Leone G, Scardamaglia P, Pate G, Verrico M, et al. Cervical intraepithelial neoplasia: risk factors for persistence and recurrence in adolescents. Eur J Gynaecol Oncol 2007; 28:189-92.

38. Harper DM, Franco EL, Wheeler CM, Moscicki AB, Romanowski B, Roteli-Martins CM, et al. Sustained efficacy up to 4.5 years of a bivalent L1 virus-like particle vaccine against human papillomavirus types 16 and 18: follow-up from a randomised control trial. Lancet 2006; 367:1247-55.

39. Rama CH, Roteli-Martins CM, Derchain SFM, Oliveira EZ, Aldrighi JM, Mariani Neto C. Detecção sorológica de anti-HPV 16 e 18 e sua associação com os achados do papanicolaou em adolescentes e mulheres jovens. Rev Assoc Med Bras 2006; 52:43-7.

Submitted on 11/Mar/2008

Final version resubmitted on 19/Jun/2008

Approved on 04/Aug/2008 